\title{
Can Online Forums Be Designed to Empower Local Com- munities?
}

\author{
Kerill Dunne
}

45 Inis Fail, Old Bawn, Tallaght, Dublin 24, Ireland. Email: kerilldunne@yahoo.co.uk

\begin{abstract}
There has been a growing concern regarding political disengagement among citizens within western representative democracies. This concern has brought about calls for local communities to be empowered by giving citizens more control over local decision-making. The objective of this paper is to examine if local political online forums can be built to empower local communities. That is to say, this paper will test if the E-Democracy.org's Local Issues Forum Guidebook recommendations (A to do list for building successful online forums) actually work and produce forums, which facilitate citizens to have a greater say on local decision-making and thus, induce empowerment. In order to test these recommendations a two-pronged methodological approach was taken. Firstly, using these recommendations an online forum was constructed in-conjunction with a local authority within the UK. Secondly, the recommendations were tested again except in this second approach a sample of online forums from around the world was examined. This paper argues that the EDemocracy.org's recommendations do not always produce forums, which empower local communities - Based on lessons learned from both experiments new guidelines are provided.
\end{abstract}

Keywords: E-Democracy, E-Participation, online forums, deliberation, ICT, political participation.

There has been a growing concern regarding political disengagement among citizens within western representative democracies. This concern has brought about calls for local communities to be empowered by giving citizens more control over local decision-making. There are countless methods for empowering local communities, however, "Whilst policy interest in e-participation is now long-standing, the links between e-participation and community empowerment are largely unproven." (Department of Communities and Local Government, 2009, p. 7). E-Participation is "normally used to refer to a narrower set of devices which facilitate the direct engagement of citizens in the policies and decisions of government bodies." (Department of Communities and Local Government, 2009, p. 73). E-Participation can be seen as part of E-Democracy, defined here as: an electronic decision making mechanism that allows citizens to make or influence decisions online about the rules under which they are going to live. There are many ICT tools available to use to provide a platform for E-Participation; this paper has chosen one of these to study - a local political online forum, which is a web, based forum that has a threaded, asynchronous platform for discussion open to all individuals within a local area to discuss local political issues from a non-consensual position.

If online forums are to be used to empower local communities it is important to build them correctly. The objective of this paper is to examine if local political online forums can be built to empower local communities. That is to say this paper will test if the E-Democracy.org's Local Issues Forum Guidebook recommendations (A to do list for building successful online forums) actually work and produce forums, which facilitate citizens to have a greater say on local decision-making and thus, induce empowerment. It is important to test these recommendations because without empirical evidence of their effect, E-Participation promoters could be implementing misleading recommendations.

The next section will present some of the theoretical discussion surrounding empowerment and participation. Section 2 will detail UK policy attempts at inducing empowerment via E-Participation; section 3 will show how the E-Democracy.org's Local Issues Forum Guidebook recommendations were used as part of an experimental case study, which produced a local political online forum in conjunction with a local government within the UK - Guildford Borough Council (GBC). In order to confirm the results obtained from the GBC experimental case study the E-Democracy.org's Local 
Issues Forum recommendations were again tested, but this time they were examined across a bigger sample of 138 local political online forums from around the world - section 4 presents this methodological approach and analysis. The final section shows how the E-Democracy.org's 'Local Issues Forum' recommendations require revision and presents new guidelines from lessons learned from both experiments. The concluding section also provides a broader theoretical discussion on E-Participation and empowerment.

\section{Participation and Empowerment}

It has long been proven that high levels of social capital (social networks built on civic engagement mechanisms such as volunteerism and voting) are highly beneficial for citizens and their communities and facilitate many things including trust, coordination and cooperation (Putnam, 1995). However, what exact type of empowerment occurs through civic engagement and can such empowerment be sustained via ICT?

Onyx and Benton (1995) argue that the concept of empowerment comes from the discourse of community development and is linked to participation. Broadly speaking, political participation is a mechanism by which citizens express their political attitudes, beliefs, opinions, and attempt to influence goals or implement policies (Clarke et al., 2004). In attempting to influence decision-making, participation can take many forms - voting, demonstrating, canvassing, and engaging in community activities. Onyx and Benton go on to say that participation is empowering for society as it allows citizens to be involved in decisions that affect their lives and it increases citizens' knowledge and skills base.

Using Rousseau (1968), Pateman (1970) argues that participation has a psychological impact on participants. This impact occurs via an interrelationship between institutions and the social/political attitudes and characters of citizens. This is the Educative Function of Participation. It educates citizens to vote for the "general will," or common good and not for their own private interests. Within a participatory democracy, an individual must get cooperation from others if $s /$ he is to get an action accepted. By participating, an individual learns that s/he must take into account wider matters than his/her own private interests and that public and private interests are linked. Within a participatory democracy, an educated citizen can distinguish between his or her own private desires, and s/he learns to be a public, as well as a private, citizen. Eventually, via this education, an individual sees no conflict between public and private interests. Once a participatory system is set up and citizens are engaged, it becomes self-sustaining. That is, the qualities required for such a system to work are those that the process of participation develops and fosters. The more one participates the better able one is to do so in the future. The educative effects on citizens that results from participation include: development of a sense of political efficacy (a sense of political competence in performing civic duties); broadening of citizens' outlooks and interests; development of an appreciation for the connection between public and private interests; an increase in familiarity with democratic procedures and the learning of democratic skills. This paper defines empowerment as the Educative Function of Participation.

Such empowerment can be achieved by face-face social networking but can it be achieved via ICT? Using Deliberative Opinion Polling (Deliberative polling consists of giving participants literature on a particular issue, allowing them to deliberate on that issue, and then surveying participants' pre- and post-deliberation), Fishkin et al.'s (2004a) research shows that both online (voicebased) and face to face deliberation produce similar results i.e. after participating within the research participants became more informed and changed their political views towards a more "internationalist slant." However, this does not represent the Educative Function of Participation i.e. there is no evidence that participants: voted for the common good, developed a political competency in performing civic duties; developed a familiarity with democratic procedures and learned democratic skills. Furthermore, there are barriers to such empowerment occurring via ICT, which need to be mentioned here. Firstly, this paper is aware that the digital divide excludes many groups of people from engaging with online forums, and thus, reduces the ability of forums to support community empowerment. Normalization Theory holds that elite groups and the traditional politically 
engaged continuing to dominate political engagement online, and bring with them all of the existing biases of the current political system (Gibson et al. 2003). However, Gurstein argues:

"Community Informatics $(\mathrm{Cl})$ is the application of information and communications technology (ICT) to enable and empower community processes. The objective of $\mathrm{Cl}$ is to use ICT to enable the achievement of community objectives including overcoming Digital Divides both within and between communities. But $\mathrm{Cl}$ goes beyond discussions of the Digital Divide to examine how and under what conditions ICT access can be made useable and useful to the to the range of excluded populations and communities and particularly to support local economic development, social justice, and political empowerment using the internet." (Gurstein, 2007, p. 13).

Secondly, local western democratic power, for the most part, resides in the hands of local authorities. Dispersing this power to local communities (direct democracy) via E-Participation initiatives will be extremely difficult.

"The shaping and guiding of this society \{network society\} is, as has always been the case in other societies, in the hands of the public sector, regardless of ideological discourses hiding this reality. And yet, the public sector is the sphere of society where new communication technologies are the least diffused and where organizational obstacles to innovation and networking are the most pronounced. Thus, reform of the public sector commands everything else in the process of productive shaping of the network society." (Castells, 2005, p. 17)

The third barrier is Heidegger's (2003) argument concerning technology. Due to the constraints limited by this paper it is impossible to give a thorough account of Heidegger's theory of technology, so please see references below for full description. Heidegger argues that within the technological age humans' experience objects, including other human subjects, as Standing Reserves (efficient means to achieve a certain end). This means that all objects within the world are organised to get greatest possible use out of them i.e. everything is transformed to become efficient and flexible without fixed properties (meaning or significance) that would otherwise constrain what we do with them.

Heidegger argues that objects are revealed in a specific way within the technological era which he calls Challenging (driving the maximum yield at the minimum effort). This Challenging puts objects under the demand to supply energy, which can be stored. Thus, the energies of objects are unlocked, exposed, transformed, stored up and distributed. All objects are ordered to be immediately on hand (Standing Reserve), and such objects appear as mere resources, which conceal what they really are. This Revealing does not occur externally to all human action and nor does it happen solely within humans.

Heidegger says that the essence of technology is nothing technological, but it is Enframing, "Enframing is the gathering together which belongs to that setting-upon which challenges man and puts him in position to reveal the actual in the mode of ordering as standing-reserve."(Heidegger, 2003, p. 259). Enframing reveals objects (including humans and their activities) within the world as Standing Reserves. This revealing excludes other non-instrumental possibilities of revealing such as Brining Forth and conceals the process of revealing itself i.e. Unconcealment (Heidegger, 2003).

Politically engaging with individuals with fixed properties requires us to develop social skills. ICT do make politics more convenient for citizens and provide an efficient form of conducting democracy, however, in the calls to implement E-Democracy we must be vigilant that ICT don't reveal politics as a mere Standing Reserve that does little to empower (Educative Function of Participation) citizens.

With these three caveats in mind this paper will examine if online forums can be designed to empower local communities i.e. increase the political participation of citizens within local decision making processes that affect their lives, and thus, induce the Educative Function of Participation. 


\section{UK Policy Attempts at Inducing Empowerment}

In order to conduct this research a forum was constructed in the UK and a sample of 138 online forums from around the world was collected. Although the latter is an international sample, the focus of this paper centres on UK policy attempts at inducing empowerment via online and offline mechanisms. In 2006 an online forum (localvisionforum.net) was set up by the British government to allow citizens to discuss the future of local government. One of the purposes of this forum was to focus discussions on "devolving decision making and empowering communities at a grass root level" (Egovmonitor, 2006). Another purpose of the forum was to gather the views of citizens and stakeholders on restructuring local government for its Local Government White Paper - Strong and prosperous communities (2006), which aimed to empower citizens and their communities by allowing them to have a greater say on things that mattered to them at the local level. Furthermore, the Local Government White Paper - Communities in control: real people, real power (2008) aimed to empower local communities by giving them control over local decisions i.e. transferring political power (decision making) from political elites to local communities. Finally, The Localism Bill (2010 2011) aims to devolve greater powers to neighbourhoods and give local communities more control over housing and planning decisions; it also aims to provide citizens with the ability to trigger local referenda. (UK Government, 2011).

The Empowering Communities to Influence Local Decision Making Report (Department of Communities and Local Government, 2009) reviewed the published evidence around community empowerment. Although independent to the British government's Communities in Control White Paper, it was designed to explore evidence that might support its implementation. The study identified key criteria that drive empowerment across six mechanisms - one of these was EParticipation. The Review found that those who directly participated in the E-Participation mechanisms were empowered i.e. their internal sense of political efficacy grew. However, E-Participation was found to be weak in empowering (enhancing social capital) the wider local community and it had a very limited impact on decision makers. Key factors which the review identified as being influential in delivering individual and community empowerment and impacting upon decision making were: the presence of a highly salient issue within the online application, the presence of effective moderation and clear links to decision-makers. The review's findings suggest that the solution to this problem may lie in combining E-Participation with offline engagement mechanisms (Department of Communities and Local Government, 2009). Moreover, the review's authors noted that across all mechanisms, including E-Participation, it was found that those that did engage and thus reap the benefits of empowerment where those that already had a capacity to do so. The review stated that working with the community and voluntary sectors and their techniques will allow engagement mechanisms to reach, and thus empower hard to reach groups.

"This research has also shown the importance of integrating mechanisms into an overarching strategy for empowerment that is set within a mainstreamed agenda of building trust with the public at every opportunity." (Department of Communities and Local Government, 2009, p. 9).

\section{GBC Experiment}

Below the theoretical recommendations that were used to build a forum in conjunction with Guildford Borough Council (GBC) will be introduced. This will be followed by a description of the access negotiations and how the forum was implemented. Finally the result of the experiment will be shown.

\subsection{Theoretical Recommendations}

The theoretical recommendations that were used are collated here under four headings: technology; developing a set of rules, objectives and promotion; and moderation. The final heading 
below (Democracy.org's 'Local Issues Forum Guidebook' recommendations) provides a synthesis of this learning.

\subsubsection{Technology}

Edwards (2004), E-Democracy.org and Street and Wright (2007), among others, say that by using certain recommendations local political online forums can be built to be successful and support participation and deliberation. Coleman and Gotze (2001) argue that successful online engagement is mainly related to social, cultural and organizational issues; whereas technology is only of secondary importance. However, the authors note that appropriate technologies are still of fundamental importance to the success of online public engagement. Online deliberative models engaging the public should make digital technologies 'people friendly'. Such issues include accessibility, usability, reliability and security (Coleman and Gotze 2001; Noveck, 2004). The Online Consultation Technologies Centre of Expertise re-emphasises accessibility, whereas Preece (2000) suggests online engagement should have registration processes and good security measures.

The OECD (2003) report Promise and Problems of E-Democracy presents research findings which calls for E-Engagement systems to have easy navigation e.g. don't overload the home page with text, and high usability e.g. all images should be given tags with a text description. Finally, Street and Wright (2007) and Lukensmeyer and Torres (2006) argue that deliberation is also encouraged by developing forums which are asynchronous and threaded.

\subsubsection{Developing a Set of Rules, Objectives and Promotion}

Trenel (2004) says that for online forums to be able to enhance the effectiveness of their outcomes, they must have at their heart equality and respect between citizens, and these are achieved by implementing a set of rules. Coleman and Gotze (2001) and Burkhalter et al. (2002) argue that citizens within online and offline deliberative models need to be protected by constitutional rights (a set of rules) in order that they can participate as equal partners in such models. Without rules such forums become anarchic (Davis, 1999, and Jensen et al. 2002; Jensen 2003). Others also state that online consultations and discussions should have a clear purpose and a recruitment drive (Coleman et al. 2002; Ferguson 2006; Office of e-Government 2005). The OECD (2003) report Promise and Problems of E-Democracy calls for online engagement to have good recruitment and promotion campaigns and clear objectives.

Forums and online events should also contain a set of goals and an agenda (Kleiber, Holt, Swenson, 2007; Online Consultation Technologies Centre of Expertise 2004; White 2002). Furthermore, the Online Consultation Technologies Centre of Expertise (2004) suggests clear channels of communication need to be set up between online forums and decision makers.

\subsubsection{Moderation}

Within the E-Democracy literature there is consensus that online forums require a trusted independent moderator/facilitator (Coleman and Gotze 2001; Beierle 2004; Steven Clift www.publicus.net; Trenel 2005, Fulwider 2006). Jensen et al. (2002) and Jensen (2003) claim that structured online forums are more deliberative than USENET forums which are unstructured i.e. forums without rules or a moderator. Indeed Davis (1999) says that forums, which have no moderator, become un-deliberative and anarchic.

Edwards (2004) argues moderators can contribute to interactivity and openness of discussions as long as they are independent. Edwards' (2002) empirical study found that a facilitator within online discussions provides a much greater function than merely that of a filter. Edwards identifies a facilitator as a democratic intermediary, whose presence can enhance the quality of discussions within a forum. He points out that facilitators manage key discussions, and contribute to interactivity, and openness of discussions. 


\subsubsection{E-Democracy.org's 'Local Issues Forum Guidebook’ Recommendations}

One of the first promoters of online forums was E-Democracy.Org which was established in 1994 as an American election orientated website. The organization has now expanded its role to encompass all E-Democracy activities. Their mission is centred on expanding participation and developing stronger democracies and communities via the use of ICT; and one of their goals is "Engagement: Strengthen, expand, and diversify engagement through effective and meaningful online discussions and information exchange on public issues" (E-Democracy.org, 2009). As part of their work, they have helped communities in the UK and US set up local political online forums.

E-Democracy.org is an organization, which has over ten years experience of promoting EDemocracy and online forums. A key document in terms of developing a successful local political online forum is the E-Democracy.org's Local Issues Forum Guidebook, which is a to-do list for those interested in establishing successful local political online forums. The guidebook provides a synthesis of the learning mentioned above and lists a set of recommendations. E-Democracy.org has produced these recommendations from learning accumulated through the experiences of its volunteers in implementing and managing online forums. The UK Local E-Democracy National Project and Office of the Deputy Prime Minister supported the development of the Guidebook and its recommendations - table 1 is a summary of these forum development recommendations. In order to test the relevance of these recommendations they were used to construct a forum in conjunction with GBC.

\begin{tabular}{|l|}
\hline \multicolumn{1}{|c|}{ Forum design qualities } \\
\hline Create a steering committee \\
\hline Have an independent moderator \\
\hline $\begin{array}{l}\text { Develop a set of rules which includes promo- } \\
\text { tion of equality and respect }\end{array}$ \\
\hline $\begin{array}{l}\text { Use technology that supports both email list } \\
\text { and web forum technology }\end{array}$ \\
\hline Launch and publicized forum \\
\hline $\begin{array}{l}\text { Make forum: accessible; secure; asynchro- } \\
\text { nous; and threaded. }\end{array}$ \\
\hline Create mission \& goals for forum \\
\hline $\begin{array}{l}\text { Forum should be set up for local geographic } \\
\text { area. }\end{array}$ \\
\hline $\begin{array}{l}\text { All posts signed by author's full and actual } \\
\text { name. }\end{array}$ \\
\hline Forum should not be exclusive \\
\hline Participants must register \\
\hline Site should be user friendly \\
\hline
\end{tabular}

Table 1: Forum development recommendations

\subsection{Access Negotiations}

In March 2005 a proposal was developed to create an online forum for a local government council within the UK (Guildford Borough Council). The head of communications at GBC became the research's gatekeeper within the council. The gatekeeper suggested choosing issues for the online forum from the GBC's Forward Plan of Key Decisions document. It took five weeks to get five GBC topics approved, transformed into questions and their relevant documentation placed within the forum. Among others, topics included: A) How can Guildford Borough Council develop an improved Museum Service? B) Where is the best location for new housing in Guildford? 
The forum began on 1 October 2005 and after a month in use very little activity had taken place. Only sixteen citizens registered as users to the forum and only five messages were posted to it. On the basis of these results it was decided to negotiate permission to place more contentious GBC issues within the forum, such as: A) Would you support the issuing of casino licenses in Guildford? B) What level of council tax increase would you accept for 2006/07?

\subsection{Implementing the Forum}

To ensure that the GBC online forum's design in itself did not hamper deliberation or participation, the online forum was developed on lessons already learnt. The entire process of setting up a local political online forum in conjunction with local government will be presented here. The purpose of this section is to detail how the E-Democracy.org's Local Issues Forum recommendations were followed to their fullest in this case study. This was done to examine if they could produce a successful forum and to detail lessons learnt from the process in order to provide new recommendations for others interested in building forums in conjunction with local government. This section shows: how the forum was promoted; why a steering committee was set up; which technology was used; why pre-moderation was chosen; ethical issues considered and finally how the forum operated will be presented.

\subsubsection{Promotion}

E-Democracy.org's Local Issues Forum Guidebook states that local online forums need to be extensively advertised. The following section details all the publicity and promotion generated for the GBC online forum. As can be seen below and in section 3.3.3 a lot of time, money and effort went into promoting the GBC online forum over a six-month period.

The advertising and promotion of the forum included: an article for 'About Guildford' newsletter (delivered to all houses in Guildford in November); a short piece and accompanying web-link was produced for the GBC website and was put on the council homepage; a promotional email was developed and sent to both GBC's parish council and tenant association email lists; a second promotional email was also developed and sent both to the Royal Society for Arts (RSA) in Guildford and community/voluntary organizations in Surrey (these organizations included groups traditionally associated with the digital divide such as: Age Concern Surrey, Surrey Alcohol and Drug Advisory Service, Surrey Council for Voluntary Youth Services, Surrey Healthy Living Program, Surrey Community Action, Guildford Refugee Action Group). The Guildford Citizens' Advice Bureau (CAB) also promoted the forum to citizens.

An article about the online forum appeared in the Surrey Advertiser (local Surrey newspaper). A pre-recorded interview (conducted with me) was aired by Eagle FM (local commercial radio station for Surrey \& Hampshire). Finally an advertisement about the forum appeared in the Friary and St. Nicolas Community Safety Update Newsletter.

\subsubsection{Steering Committee}

E-Democracy.org Local Issues Forum Guidebook argues that a steering committee is useful for setting up a successful local political online forum. A steering committee was set up for the GBC online forum to serve as a non-partisan, non-profit, trusted host for the online forum and its issues. The steering committee oversaw the ongoing development of the forum. In short the role of the steering committee was to prevent one individual or organization censoring the forum or limiting the discussion within the forum. The forum moderator was also held accountable to this steering committee. Various community voluntary organizations in Guildford were emailed requesting them to join the online forum's steering committee. The response to this email was poor, but one individual, a community development worker with the Healthy Living Programme became a member of the GBC steering committee. The steering committee also included local representatives (cross party) and academics. 


\subsubsection{Second Round of Advertising}

After its first month in use very little activity took place within the forum. Following a discussion on this at a steering committee meeting, it was decided to conduct another round of access negotiations with GBC officers and re-advertise the forum.

A description of the online forum and web link was placed on BBC Action Network website. Following this a promotional article was written for the BBC action network's 'Take Action Week'. Furthermore, an advertisement regarding the forum appeared in Surrey Advertiser, and a follow-up article about the online forum appeared in the Surrey Advertiser. Two hundred leaflets advertising the forum were also printed and distributed to: Guildford Library; GBC's reception area; two supermarkets; the community \& voluntary sector via the Healthy Living Programme; and Cafes throughout Guildford.

\subsubsection{Technology Used}

GroupServer software was the first software employed to build the GBC online forum for this research. GroupServer software was chosen because it combined web forum and email list technology, which is supposed to induce deliberation and promote convenience for users (EDemocracy.org's Local Issues Forum Guidebook). Convenience here means participants do not need to visit a web forum to participate; they can do so via their inbox. GroupServer software was promoted by the Office of the Deputy Prime Minister (ODPM) and prominent E-Democracy advocate Steven Clift - "GroupServer is the best social software platform we've seen to date for online communities that average citizens actually use" (Clift, 2006). The UK local E-Democracy National project (via ODPM) provided funds to support the 'GNU General Public License' (GPL) open source release of GroupServer software. GroupServer software is written in Zope, advanced XML standards and Python. However, many technical difficulties arose in setting up GroupServer on the Department of Sociology's (University of Surrey) web server. These technical difficulties continued and with the timeframe allowed it was decided to find other software.

Market research was conducted in order to rate different forum and bulletin board software products against certain required criteria. The software chosen was DiscusWare (www.discusware.com) Freeware software. However, Discus Freeware like the other applications had no self-registration mechanism, no message queue system and no registration form for capturing demographic information - all of which were required for the research. In order to obtain these facilities it was decided to upgrade to Discus Professional for a cost of $\$ 149.95$.

Furthermore, Discus Professional had no poll feature, and the process of including such a feature in the software was arduous. Thus, it was decided to source external poll software. It became apparent that pasting a HTML poll code into the site directory would take a lot of time to achieve this was because the HTML poll code had to be configured to Discus Professional formatting. It was decided to source a poll website that generated a URL link directly between its website and the online forum. After reviewing many such sites (www.Ballot-box.net, www.pollhost.com, and www.freepolls.com), Sparklit Gold Poll software (webpoll.sparklit.com) was chosen because it contained such features as: email verification; advertisement blocking; cookie blocker (prevents users voting twice from the same pc); IP blocking (prevents users voting twice from the same IP address); voter logs (logs person's vote, IP address and email address); and hide results (prevents users from viewing poll results during the vote). In terms of security, especially in relation to the voting arena within the forum, the Electoral Commission report Modernising Elections (2002) argues that E-Voting and internet voting advocates are a long way from re-assuring the general public on security fears, and a lot more is required to make such systems safe - this also held for the voting mechanisms within this forum.

To ensure accessibility, usability and reliability the GBC online forum was built and designed using the following web design texts and web sites: Nielsen (www.useit.com/alertbox), (1999), (2003), (2004); McClung-Genevese (2005); Makrevski (2004); CSUS (2002); Lynch and Horton (2004); Lengel (2002); and Ericksen (1999). The GBC online forum was also developed using the World 
Wide Web Consortium (W3C) Web Accessibility Initiative (WAI) Web Content Accessibility Guidelines 2.0, and E-Government Unit UK Cabinet Office (2002) report. Moreover, the forum was developed with limited graphics and the graphics that were used had text descriptions. The website was also passed through Bobby software (webxact.watchfire.com) and its quality, and accessibility was assured.

\subsubsection{Pre-Moderation}

Lukensmeyer and Torres (2006) argue that forums should be pre-moderated - this entails previewing all messages before allowing them to be posted within a forum. Post moderation means reviewing messages after they have been posted. Pre-moderation was chosen to prevent libellous messages being posted onto the forum. This was done because the moderator, under UK law, would have been held liable for allowing defamatory messages to be posted within the forum. Premoderation was used to filter all the posted messages and ensure they complied with the forum's rules (see appendix A). As forum moderator I did not have any allegiances nor belong to any British political party. In this light, the research was conducted impartially and independent of any political persuasions. The forum moderator's duties included: enforcing the rules of the forum; responding to participants' questions; providing basic technical support to users; focusing discussions within the forum; and compiling the results of the votes at the end of the forum. Messages, which transgressed the forum's rules, were prevented from being posted. During the GBC online forum's existence only one post was prevented from being posted. The post was libellous towards a businessman within the Guildford town area.

Edwards (2004) argues that what a moderator deletes or deems irrelevant is a biased subjective process and it is impossible for a moderator to be unbiased. However it is possible as a moderator not to un-duly censor posts. This was the approach taken within the GBC forum. As the forum was not active it was quite easy to pre-moderate all posted messages and this was done quickly to allow discussions to flow. However, if the forum had been more active it would have been more difficult to pre-moderate all members' messages.

\subsubsection{Study Population \& Ethical Considerations}

To begin with, this section will detail whom this project was targeted at, and secondly it will present some of the ethical considerations that needed to be heeded as part of this research. The study population of this research was comprised of private citizens living in the Guildford area. Citizens could contribute to the debates within the forum, but only those individuals who were: eighteen years of age and over; lived within the Guildford area; and were British, Commonwealth, or European citizens could vote within the GBC online forum. These criteria were used, as they were the eligibility criteria used for voting within local borough elections.

The online forum explicitly informed participants about the purpose and nature of its existence and the subsequent use of the posts for academic purposes. Participants were also made aware that the results of the votes within the forum were to be presented to the GBC executive. Participants to this research could not be guaranteed confidentiality because real names had to be used on posts within the forum (see table 1 above).

In the second month of the forum's existence a member of the public queried whether the forum was in breach of the law. The individual in question said that they registered for the forum and were asked for their email address. This individual noted that there was no opt-in question asking them whether they were happy to receive third party emails, they claimed it was now legally binding to ask such a question. The Joint Information Systems Committee Legal Information Service (JISC Legal) was immediately contacted and said that if one collects email addresses with intent to pass them to third parties, one should be in compliance with the Data Protection Act 1998. At this stage clearer text was placed on the registration section of the forum stating that if a participant selected email notification as part of their registration, this would mean third parties would be able to email them. The text within the registration section, which made participants aware that they could hide 
their email address from other users, was also made more explicit. All previous registered users were emailed to highlight this issue. Finally, the data protection and information compliance officer was consulted at the University of Surrey, who after completing the registration process of the forum said that the website fulfilled the information requirements of the Data Protection Act. However, he noted that it would be prudent to amend the registration page and tell participants what the project intended to do with all email addresses in relation to the research - this was done. Thus, it is important when implementing any E-Participation mechanism to become fully aware of all legal implications of such mechanisms in order to protect citizens and E-Participation promoters.

\subsubsection{How the Forum Operated}

The format of discussion and voting mechanisms within the GBC forum will be presented here. A statement of aims and objectives were devised for the forum along with a set of rules (Appendix $A$ ) and participants had to register to the forum by agreeing to abide by these rules. After this, participants could enter the online forum with a username and confidential password. The general public could read all posts within the forum, but users had to be registered to post within the forum. At registration participants were asked for some demographic information. Discus Professional allowed citizens to post to the forum in two ways: 1, via the forum's website; and 2, by replying to an email from the forum. Each message posted to the forum was threaded under a GBC sub-topic. Discus Professional software's interface allowed the moderator to manage the content within the forum and place documents within for sharing. If a participant posted a message on the forum it was emailed onto all other members who had enabled email notification within their registration. Apart from the sub-topics chosen from the GBC Forward Plan of Key Decisions document, the forum had two other fixed subtopics: one, the voting arena and two, a discussion space for citizens to discuss other local issues not set by the moderator. Each sub-topic had either a web-link or attached document providing background information for participants. Once the discussion period on a particular issue had finished participants could vote on that particular issue. However, the results of votes on only two separate issues were presented to the GBC executive; please see section below for results of these ballots. Furthermore, the GBC executive was under no obligation to vote in line with the preference formed by this online forum.

\subsection{Result of the GBC Experiment}

By implementing the GBC online forum Guildford Borough Council fulfilled a part of their obligations to the Office of the Deputy Prime Minister's strategy for local E-Government, and further implemented their E-Government priority outcomes for 2005. GBC used the online forum to complement its other offline consultations activities; the problem with this approach was that it limited the online forum to what the borough council already did i.e. it was an add-on to existing services and did not change the way the council interacted with the borough (Pratchett, 2006). As a result the GBC forum did little in terms of empowering the local community in Guildford.

After all that was implemented above and done in accordance with the E-Democracy.org's Local Issues Forum recommendations the forum failed and citizens did not participate in it. In order to increase participation among citizens, two contentious local government issues were placed in the forum. These were: whether Guildford should have a casino license; and what level of council tax would the citizens of Guildford accept. However, despite the placement of these two issues within the forum participation was still almost non-existent.

Between 1 October 2005 - 22 January 2006 hardily any activity took place within the forum, only fifty eight users registered for the forum and the forum only received twenty eight posts. An interesting finding here was that more people looked at the website than registered, posted or voted within it. The GBC online forum closed on the 29 March 2006 with only sixty eight registered users and fifty eight posted messages; and as can be seen in figure 1 and figure 2 very few people took part in the voting processes within the forum. Thus, in this case study, the use of EDemocracy.org's Local Issues Forum recommendations failed to produce a forum, which empowered the local community. 


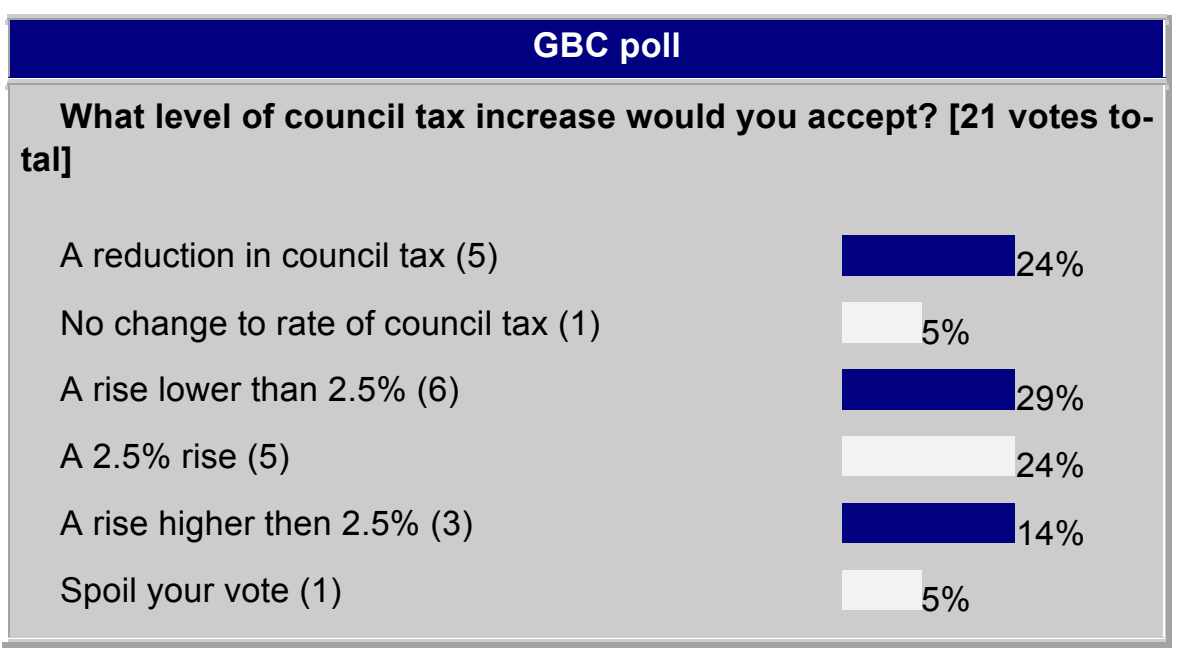

Figure 1: Result of first issue voted on.

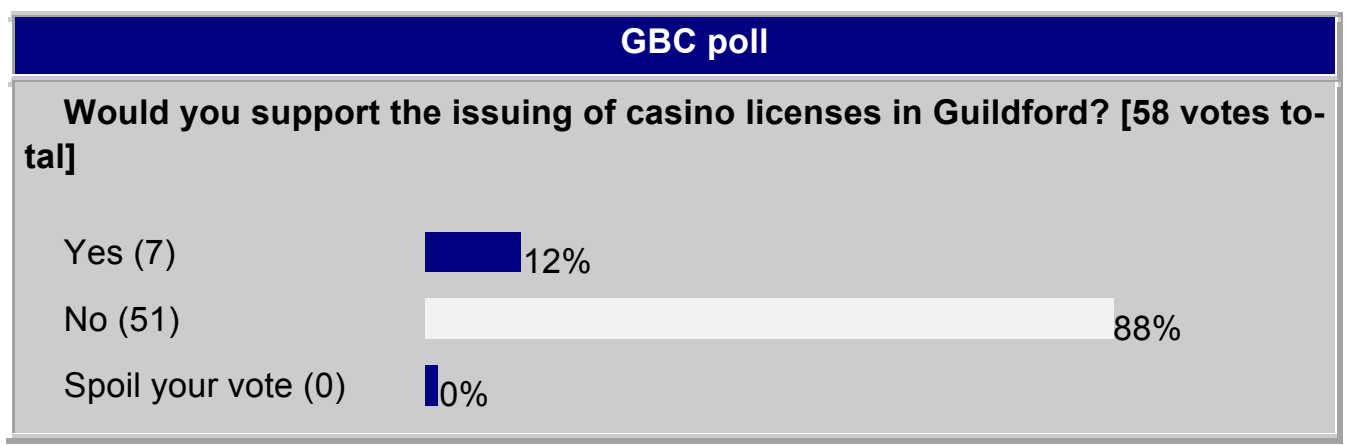

Figure 2: Result of second issue voted on.

As was shown above the use of E-Democracy.org's Local Issues Forum recommendations (including the use of moderation and a steering committee) did not produce a forum, which empowered the local community. However, it was useful to set up a steering committee (made up of representatives from local government) to assist in pushing forward E-Participation project agendas within local government, but this had no impact on the success of the forum.

\subsubsection{Reasons for Failure}

There are various reasons why this experiment may have failed. Firstly, it could have failed because citizens within Guildford may have not heard about the forum; however this is unlikely to have been the case because, as was shown above the forum was extensively advertised throughout the borough. Secondly, the forum could have failed because of a lack of Internet access, but Guildford is located in a high Internet access area. Sixty one per cent of households in Britain have Internet access and sixty five per cent of households in the South East of England (where Guildford is located) have Internet access (National statistics office, 2007). Furthermore, a promotional email was sent to groups who are affected by the digital divide such as: Age Concern Surrey, Surrey Alcohol and Drug Advisory Service, Surrey Council for Voluntary Youth Services, Surrey Healthy Living Program, Surrey Community Action, Guildford Refugee Action Group. Moreover, various community voluntary organizations in Guildford were emailed requesting them to join the online forum's steering committee. Finally, citizens may have not participated within the forum because Guildford is an affluent middle class borough where local government issues have no importance. 
However, this was not the case because only 56 per cent of residents in a 2005 Market \& Opinion Research International (MORI) poll of 1000 residents were satisfied with the way GBC ran things in the Borough (GBC, March 2006, p. 3).

Even though these other possible reasons for failure have been eliminated it cannot be said for certain that forums built using the E-Democracy.org's Local Issues Forum Guidebook recommendations will be inactive and will do little to empower communities. The forum could have still failed by some other unknown reason. However "Institutional design plays an important role in determining whether groups of citizens are able to gain access to decision-making" (Lowndes and Wilson, 2001, p. 641). Lowndes, Pratchett and Stoker's (2006) research on participatory activities within six English localities shows that while community ties (social capital) and the socio-economic position of citizens within communities shapes levels of political engagement they do not determine them. They argue that the way institutions of local government work and how their members and officials view participation mechanisms also influences whether people participate or not. Levels of participation are "found to be related to the openness of the political system, [and] the presence of a public value orientation among local government managers" (Lowndes, Pratchett and Stoker, 2006 b, p. 539). Thus, E-Participation needs to be nestled in broader local government reform processes and Pratchett, Wingfield, and Karakaya-Polat (2005) provide recommendations on how to achieve this. However, if citizens are dissatisfied with the system of representative democracy, then the implementation of the GBC forum, situated within a local representative democracy, would prove fruitless in encouraging political participation and community empowerment.

\section{Forums from Around the World}

Once the first methodological approach was completed it was decided to systematically test the E-Democracy.org's Local Issues Forum recommendations again, but in this second approach it was decided to focus on a sample of local political online forums from around the world. This second approach was taken to see if the results from the first experiment were also present in a wider population of local political online forums.

\subsection{Methodology}

This section will focus on detailing the process by which a sample of 138 local political online forums from around the world was selected. The research could have just focused on forums within the UK, but a big enough sample to analyze could not be gathered. Below the criteria devised and the sampling/collection processes used will be spelt out.

\subsubsection{Criteria}

Two sets of criteria were used to select a sample of local political online forums from the Internet. The online forum selection criteria are shown in the right hand column of table 2 . The left hand column shows the political selection criteria used, which were developed on Barber's (1984) basic theoretical conditions that give rise to politics. Although the two sets of criteria are presented side by side in table 2 , there is no correlation between them. 


\begin{tabular}{|c|c|c|}
\hline & Political criteria & Online forums criteria \\
\hline 1 & Necessary public action required & Situated on the English speaking World Wide Web. \\
\hline 2 & $\begin{array}{l}\text { There has to be public choice on } \\
\text { local issues. }\end{array}$ & Did not require registration to read posts \\
\hline 3 & $\begin{array}{l}\text { Absence of independent ground } \\
\text { i.e. conflicting viewpoints }\end{array}$ & $\begin{array}{l}\text { The general layout was not that of a blog or a listserv or } \\
\text { email list (unless list had archived threads). There had } \\
\text { to be (the potential for) more than one contributor, each } \\
\text { providing distinct, signed input, which remained on a } \\
\text { message / discussion / bulletin threaded board. }\end{array}$ \\
\hline 4 & Issues which affect all participants & Moderated or un-moderated \\
\hline 5 & $\begin{array}{l}\text { Forums which are exclusionary } \\
\text { i.e. the Republicans' forum were } \\
\text { not collected. Nor were forums } \\
\text { which were set up for one single } \\
\text { issue e.g. environmentalism. }\end{array}$ & A rules based framework \\
\hline 6 & $\begin{array}{l}\text { Forums had to have a thread } \\
\text { dedicated to a village, town or } \\
\text { city; and not just threads for prov- } \\
\text { ince, state or international issues. } \\
\text { However, forums, which were set } \\
\text { up exclusively for local issues, } \\
\text { could contain some wider issues. }\end{array}$ & $\begin{array}{l}\text { In the most general sense forum provided a format for } \\
\text { citizens to participate in local / national decision making } \\
\text { or input into policy formation }\end{array}$ \\
\hline 7 & & $\begin{array}{l}\text { All citizens, private organisations and government offi- } \\
\text { cials had to be allowed to participate within forum. }\end{array}$ \\
\hline 8 & & $\begin{array}{l}\text { Forum could be independently, privately or governmen- } \\
\text { tally run. }\end{array}$ \\
\hline
\end{tabular}

Table 2: Criteria used to select forums

\subsubsection{Sampling Strategy and Data Collection}

The sampling strategy began with the development of five search phrases (see table 3 below). These search phrases were used within the search engine Google to locate relevant forums. The search phrases were used individually across the Internet as a whole and not searched through geographically specific areas. Google's most relevant search result pages (results which incorporate popular sites) were only examined; Google's omitted results pages were not. Google's omitted results feature incorporates less relevant Web links in the search results; this feature was not used as it produced duplicative and irrelevant results. The sample itself at the end of the data-collection process contained 138 forums. Furthermore, by using the search engine Google the data and results here are slightly unrepresentative. Forums, which have less links to them, have a weaker chance of being selected by the search engine Google. In terms of this research this does not bias the results of this study to any great extent because the research was more concerned with popular and active forums rather than inactive unpopular forums. 


\begin{tabular}{|r|l|l|l|}
\hline & \multicolumn{1}{|c|}{ Phrase } & $\begin{array}{c}\text { Number of forums } \\
\text { examined }\end{array}$ & $\begin{array}{c}\text { Number of Google } \\
\text { pages }\end{array}$ \\
\hline 1 & Online political discussion forum & 814 & 82 \\
\hline 2 & Local politics discussion forum & 440 & 44 \\
\hline 3 & Community online discussion forum & 859 & 86 \\
\hline 4 & Local government council online forum & 780 & 78 \\
\hline 5 & Local politics message board & 500 & 50 \\
\hline & Total & 3393 & 340 \\
\hline
\end{tabular}

Table 3: Search phrases and the number of forums explored

Data entry took two months to complete; in total data collection and data entry took seven arduous months to be completed - the process was very repetitive. Data entry consisted of examining each of the 138 forums and categorizing them across variables within SPSS. The variables and the coding system used can be seen in table 4 .

\begin{tabular}{|c|c|}
\hline Variable & Codes \\
\hline Moderated & Whether forum had a moderator or not \\
\hline Inactive & $\begin{array}{l}\text { If a forum had no posts registered within it for a month it was noted as inac- } \\
\text { tive. However, a forum was also noted as inactive if it had a recent post and } \\
\text { the main body of other posts were more than a month old. Forums were } \\
\text { also noted as inactive if the forum had a recent post situated in a forum with } \\
\text { little or no other posts. }\end{array}$ \\
\hline $\begin{array}{l}\text { Core group of } \\
\text { posters }\end{array}$ & $\begin{array}{l}\text { This variable coded whether a select group of forum participants posted the } \\
\text { majority of messages within a forum. }\end{array}$ \\
\hline $\begin{array}{l}\text { Whether forum } \\
\text { had relevant } \\
\text { debate or not }\end{array}$ & $\begin{array}{l}\text { The codes here included: } \\
\text { Majority relevant debate (the majority of threads discussed local political } \\
\text { issues). } \\
\text { Minority relevant debate (minority of threads occasionally discussed local } \\
\text { political issues) } \\
\text { Non-relevant debate (no local political issues discussed within forum). }\end{array}$ \\
\hline $\begin{array}{l}\text { Capacity for } \\
\text { deliberation }\end{array}$ & $\begin{array}{l}\text { This research is aware that deliberation is a complicated and multifaceted } \\
\text { concept. However, this research does not wish to tap the concept of delib- } \\
\text { eration, rather it aims to examine a forum's basic capacity to support it. An } \\
\text { elementary component of deliberation, which is present in all forms of it, is } \\
\text { that individuals engage in dialogue rather than monologue. Thus, the codes } \\
\text { developed here are: } \\
\text { - Forums with a majority of single posts were coded as having no ca- } \\
\text { pacity for deliberation i.e. forums with a majority of singular posted } \\
\text { messages without response(s). } \\
\text { Forums with a majority of two or more replied-to posts were coded } \\
\text { as having a capacity for deliberation i.e. more dialogue than mono- } \\
\text { logue was occurring within forums. }\end{array}$ \\
\hline
\end{tabular}

Table 4: Coding of variables 


\subsection{E-Democracy.org's Recommendations Revisited}

Looking at a wider population of forums it will be examined if E-Democracy.org's Local Issues Forum recommendations (which failed to empower a local community in the GBC experiment) can produce successful forums. To note, successful is defined here as forums which: are active; do not have a core group of posters, have a capacity for deliberation; and contain (on the majority) relevant debate. Table 5 below lists a subset of forums from the research's main sample of 138 (see section 4.1 for selection criteria and sampling strategy). The 21 forums in table 5 were selected on the basis of their compliance with the E-Democracy.org's Local Issues Forum recommendations. Forums with reference numbers 1-7 are those that comply with all E-Democracy.org's Local Issues Forum recommendations including moderation and setting up a steering committee. As can be seen, both the Darebin and Guildford (GBC online forum from the last chapter) forums are inactive; and even though they have a capacity for deliberation this is set among a core group of posters, which means that forms of deliberation, which require all citizens' voices to be included, or at least their opinions represented in sufficient scale within a decision making process that affects them, cannot occur within these forums. Here, we have two forums, which fulfil all E-Democracy.org's Local Issues Forum Guidebook recommendations and are still unsuccessful.

Forums with reference numbers 8-15 are forums, which fulfil some, but not all of the EDemocracy.org's Local Issues Forum recommendations i.e. they are not supported by a steering committee. All these forums are inactive, have a core group of posters, and do not have a capacity for deliberation. Also, York talk, Seacoast, and Langunatic have a majority of non-relevant debate occurring within them. Although these forums fulfil a majority of the E.Democracy.org's Local Issues Forum Guidebook' recommendations they are all unsuccessful.

Forums in table 5 below with reference numbers 16-21 are forums which in part do not comply with all E-Democracy.org's Local Issues Forum recommendations i.e. these are forums which are not moderated - an essential criterion for successful forum development according to EParticipation/E-Democracy advocates. Here we can see six forums, which are successful, i.e. forums that are: active, have no core group of posters, have a capacity for deliberation, and have majority relevant debate occurring within them.

As can be seen in table 5 there are two forums within the sample which fulfil all of the EDemocracy.org's Local Issues Forum recommendations (e.g. forums which are moderated / and have steering committee) and they are still unsuccessful i.e. are inactive; and cannot support forms of deliberation, which require all citizens' voices to be included, or at least their opinions represented in sufficient scale within a decision making process that affects them. There are eight forums, which fulfil a majority of the E-Democracy.org's Local Issues Forum recommendations including moderation, but again are unsuccessful, i.e. inactive, all have a core group of posters, and none have a capacity for deliberation; and three forums have a majority of non-relevant debate occurring within them. Finally, there are six forums within the sample, which do not comply with the majority of the E-Democracy.org's Local Issues Forum recommendations and are successful i.e. forums which: are active, don't have core group of posters, have a capacity for deliberation, and have a majority relevant debate occurring within them. This research argues (like the GBC experiment findings) that the E-Democracy.org's Local Issues Forum Guidebook recommendations (moderation and the setting up of a steering committee) in all cases do not produce successful forums that empower local communities. 


\begin{tabular}{|c|c|c|c|c|c|}
\hline $\begin{array}{l}\text { Ref } \\
\text { No. }\end{array}$ & Forum & Active & $\begin{array}{l}\text { Core } \\
\text { Group of } \\
\text { posters }\end{array}$ & $\begin{array}{l}\text { Capacity } \\
\text { for deliber- } \\
\text { ation }\end{array}$ & $\begin{array}{l}\text { Relevant } \\
\text { debate }\end{array}$ \\
\hline 1 & Darebin & No & Yes & Yes & Majority \\
\hline 2 & St Paul & Yes & No & Yes & Majority \\
\hline 3 & Roseville & Yes & Yes & Yes & Majority \\
\hline 4 & Minneapolis & Yes & No & No & Majority \\
\hline 5 & Newham & Yes & Yes & Yes & Majority \\
\hline 6 & Guildford & No & Yes & Yes & Majority \\
\hline 7 & Brighton/ Hove & Yes & Yes & Yes & Majority \\
\hline 8 & York talk & No & Yes & No & $\begin{array}{l}\text { Non- } \\
\text { relevant }\end{array}$ \\
\hline 9 & Ottawa Sublet & No & Yes & No & No data \\
\hline 10 & Buena Park & No & Yes & No & Majority \\
\hline 11 & Seacoast & No & Yes & No & $\begin{array}{l}\text { Non - } \\
\text { relevant }\end{array}$ \\
\hline 12 & Pittsburgh Live & No & Yes & No & Majority \\
\hline 13 & $\mathrm{OC}$ & No & Yes & No & Majority \\
\hline 14 & Langunatic & No & Yes & No & $\begin{array}{l}\text { Non- } \\
\text { relevant }\end{array}$ \\
\hline 15 & Knowsley & No & Yes & No & Majority \\
\hline 16 & Onmilwaukee & Yes & No & Yes & Majority \\
\hline 17 & Northsuncoast & Yes & No & Yes & Majority \\
\hline 18 & $\begin{array}{l}\text { Dayton DailyN- } \\
\text { ews }\end{array}$ & Yes & No & Yes & Majority \\
\hline 19 & Greenville & Yes & No & Yes & Majority \\
\hline 20 & The Star Press & Yes & No & Yes & Majority \\
\hline 21 & $\begin{array}{l}\text { Kildare Commu- } \\
\text { nity Network }\end{array}$ & Yes & No & Yes & Minority \\
\hline
\end{tabular}

Table 5: List of online forums

\section{Conclusion}

In the GBC case study, the use of E-Democracy.org's Local Issues Forum recommendations did not produce a successful forum, which empowered a local community. This result was confirmed within the findings of the analysis of the sample of forums from around the world. These findings identified another forum, which fulfilled all of the E-Democracy.org's recommendations (moderate ration and steering committee) and was unsuccessful. The findings also showed forums, which fulfilled a majority of the Local Issues Forum recommendations including moderation, were also unsuccessful. This research identified forums, which did not comply with the majority of the recommendations and were successful. This research argues that the E-Democracy.org's Local Issues Forum Guidebook recommendations (moderation and the setting up of a steering committee) are not essential recommendations for the production of active forums (civic engagement), which empower communities; in fact un-moderated forums can produce active forums. The E- 
Democracy.org's recommendations do not, in all cases, produce active forums, which empower local communities and thus require revision.

\subsection{Lessons Learned}

The purpose of this section is to detail the lessons learned from implementing the EDemocracy.org's Local Issues Forum recommendations and provide new guidelines for others interested in building forums in conjunction with local government.

Street and Wright (2007) argue that software developers design people out of participation e.g. an individual working within a community development project with limited IT know-how would be unable to set up a forum using GroupServer. The GroupServer forum software advocated by EDemocracy.org and the Office of the Deputy Prime Minister was extremely difficult to set up technically. This research recommends for those interested in setting up an online forum to source alternative forum software that is easy to install, set-up and manage; and if possible build such forums with participants.

"Systems design for communities goes beyond just creating some technologies and offering them to user communities, assuming that they know what to do with them... From another perspective, an opportunity, even a necessity, for communities and individuals to play an active role in the design, development and deployment of systems arises from this approach. Nevertheless, this involvement puts forward new questions and challenges, as, for example, how to apply Participatory Systems Design Methodology (which is relatively resource intensive) in contexts where resources such as time or money are limited or lacking." (De Moor and De Cindio, 2007).

However, there are many different ways of conducting action research or participatory design which brings together software developers or E-Participation advocates and citizens in the development of community ICT (Preece 2000; Bieber et al. 2007; De Cindio et al. 2007). In the case of the GBC forum, as it was developed, it was continually tested. Before it was launched the forum was piloted on three different study groups comprising of five or more participants. All difficulties noted by test groups were addressed, these included: for the logos on the homepage to have URL links; for text to be curtailed on the homepage; and to clarify and justify the registration section of the forum. Also, as was shown in section 3, the forum was developed with a set of rules, a list of objectives, a set of goals and an agenda for citizens to read. Further guidelines for anyone interested in setting up a local political online forum in conjunction with local government are listed below:

1. The Department of Communities and Local Government Review (2009) identified effective moderation as a key factor in influencing community empowerment. Furthermore, within the E-Democracy literature there is consensus that online forums require an independent moderator (Coleman and Gotze 2001; Beierle 2004; Steven Clift - www.publicus.net; Trenel 2005, Fulwider 2006). Indeed Davis (1999) says that forums that have no moderator become anarchic; Jensen et al. (2002) and Jensen (2003) say moderated forums are more likely to be deliberative than those without. The results of this research show that forums, which are active and have a capacity for deliberation can be built without a moderator. Moderation is not essential in terms of designing forums to empower local communities. However, it is recommended that pre-moderation be used to protect the developers of online forums from libel actions. To note, implementing the latter could be problematic if online forum is extremely active.

2. It takes quite a lot of time and effort to reassure local government about implementing EParticipation, so be prepared for many meetings with different local government officers and representatives.

3. As soon as is possible within the process get a gatekeeper within local government on board. 
4. Allow enough time to set a forum up. In the case of the GBC it took seven months from drafting the initial proposal to the launch of the forum.

5. Be prepared to spend time and money on promoting the forum. However, where possible use free publicity e.g. local newspapers are always looking for interesting projects to write about.

6. Even though the results above show that the use of steering committees had no impact on the success of forums, the use of one in the process of running the GBC forum proved useful. Such committees (especially made up of representatives from local government) are helpful in assisting projects gain access to certain local government topics for the forum, and pushing E-Participation agendas within the local government.

7. The bureaucracy within local government means it takes time to get approval so leave enough time to get access to local government issues. It took this research five weeks to get all GBC topics approved, transformed into questions, and relevant documentation placed within the forum. In this process be prepared to chase up individual local government officers.

8. It is important when implementing any E-Participation mechanism to become fully aware of all legal implications of such mechanisms.

\subsection{Discussions}

Implementing the above recommendations (including the use of participatory design) will not in itself empower local communities. Citizens are dissatisfied with the system of western representative democracy (Barber, 1984; Pattie et al., 2004). Coleman and Gotze (2001) argue that many citizens currently feel their political views are not taken into account by the political system, and if given the opportunity citizens would indeed like to participate within online policy deliberation. When local governments develop public participation mechanisms they tend to commission sites that maintain existing institutional and cultural practices of the councils (Street \& Wright, 2007). In the process of devolving decision making power (as outlined in section 2) to local communities, local governments need to change and should not use online forums as merely add-ons to existing services and existing ways of doing public engagement. Institutions of local government also need to develop open political systems with public officials open to E-Participation tools such as online forums (Lowndes, Pratchett and Stoker, 2006). This process would need to involve: the further reduction of the digital divide; the development of more secure internet voting systems; and the combination of online forums with offline engagement mechanisms that are embedded in the techniques of the community and voluntary sector.

However, more importantly, the local political system requires readjustment, and until policy reforms devolve local decision making power more fully to citizens, citizens will not fully engage with ICT embedded in representative democracy. In tandem to the latter, the above recommendations can be implemented to design forums that increase the political participation of local communities, but such forums may not necessarily empower them. In an ideal environment where real direct democracy (decisions made at local level by citizens via referenda) is devolved into the hands of local people, the digital divide is eradicated, and local governments are geared fully towards EParticipation, there would still be issue of Enframing (Heidegger, 2003) standing in the way of ICT empowering citizens and their communities. This paper is not calling for a step backwards in terms of E-Participation initiatives, but it is calling on E-Participation advocates to reflect on what actually their goal is - either efficient policy making or empowered citizens? 


\section{References}

Barber, B. (1984.) Strong Democracy. Participatory Politics for a New Age. Los Angeles: University of California Press.

Beierle, T. (2004). Digital Deliberation: Engaging the Public Through Online Policy Dialogue. In P. Shane (Ed.), Democracy Online - The Prospects for Renewal Through the Internet (pp. 155-166). New York: Routledge.

Bieber, M., McFall, B.S., Rice, R.E. \& Gurstein, M. (2007). Towards Systems Design for Supporting Enabling Communities. Community Informatics 3(1).

Burkhalter, S., Gastil, J. \& Kelshaw, T. (2002). A Conceptual Definition and Theoretical Model of Public Deliberation in Small Face-to-Face Groups. Communication Theory 12(4), 398-422.

Castells, M. (2005). The Network Society: From Knowledge to Policy. In M. Castells \& G. Cardoso (Eds.), The Network Society: From Knowledge to Policy (pp. 3-22). Washington, DC: Johns Hopkins Center for Transatlantic Relations.

Clift, S. (2006). Groupserver. Retrieved from http://e-democracy.org/groupserver/

Cohen, J. (1996). Procedure and Substance in Deliberative Democracy. In S. Benhabib (Ed.), Democracy and Difference Contesting the Boundaries of the Political (pp 95-119). Princeton: Princeton University Press.

Coleman, S. \& Gotze, J. (2001). Bowling Together: Online Public Engagement in Policy Deliberation. London: Hansard Society.

Coleman, S., Hall N. \& Howell, M. (2002). Hearing Voices: The Experience of Online Public Consultations and Discussions in UK Governance. London: Hansard Society.

CSUS (2002). Web Design Principles. Retrieved from http://www.csus.edu/uccs/training/online/design/d_principles.htm

Davis, R. (1999). The Web of Politics: the Internet's Impact on the American Political System. Oxford: University Press Oxford.

De Cindio, F., Ripamonti, L.A. \& Peraboni, C. (2007). Community Networks as Lead Users in Online Public Services Design. Community Informatics. 3(1).

De Moor, A., \& De Cindio, F. (2007). Beyond Users to Communities - Designing Systems As Though Communities Matter An Introduction to the Special Issue. Community Informatics. 3(1).

Department for Communities and Local Government. (2008). Communities in Control: Real People, Real Power. London: Communities and Local Government.

Department for Communities and Local Government. (2009). Empowering Communities to Influence Local Decision Making - A Systematic Review of the Evidence. London: Communities and Local Government.

Directgov. (2009). Government, Citizens and Rights. Retrieved 02/07/09 from http://www.direct.gov.uk/en/Governmentcitizensandrights/UKgovernment/Parliament/DG_076367

Dryzek, J. (2000). Deliberative Democracy and Beyond. Liberals, Critics, Contestations. Oxford: Oxford University Press.

E-Democracy.org. (2005). Local Issues Forum Guidebook. London: Local e-Democracy National Project.

E-Democracy.org. (2009). Mission and Goals. Retrieved from http://pages.e-democracy.org/Mission_and_Goals

Edwards, A. (2004). The Moderator in Government-Initiated Internet Discussions: Facilitator or Source of Bias? In M. Malkia, A. Anttiroiko. \& R. Savolainen (Eds.), eTransformation in Governance: New Directions in Government and Politics (pp. 150-167). London: Idea Group.

Edwards, A. (2002). The Moderator as an Emerging Democratic Intermediary: The Role of the Moderator in Internet Discussions about Public Issues. Information Polity 7(1), 3-20.

E-Government Unit UK Cabinet Office. (2002). 2.4 Building in Universal Accessibility + Checklist. Retrieved from http://www.cabinetoffice.gov.uk/e-government/resources/handbook/html/2-4.asp

Egovmonitor. (2006). Miliband Launches Site to Spark Local Debate. Retrieved from http://www.egovmonitor.com/node/5356

Electoral Commission. (2002). Modernising Elections - A Strategic Evaluation of the 2002 Electoral Pilot Schemes. London: The Electoral Commission.

Elster, J. (1998). Introduction. In J. Elster (Ed.), Deliberative Democracy (pp. 1-8). Cambridge: Cambridge University Press. Ericksen, L. (1999). Web Page Creation \& Design - Compact Guide. Reading Massachusetts: Addison Wesley Longman.

Fishkin, J., Luskin, R., \& lyengar, S. (2004), Considered Opinions on U.S. Foreign Policy: Face-to-Face versus Online Deliberative Polling, Retrieved http://cdd.stanford.edu/research/papers/2004/online-fp.pdf

Ferguson, R. (2006). Digital Dialogues Interim Report - December 2005 - August 2006. London: Department for Constitutional Affairs. Justice, Rights and Democracy.

Fulwider, J. (2006). Can Citizens Deliberate on Their Own? An Empirical Test Using Survey Measures and Small-Group Observation. Paper presented at the Annual Conference of the Southern Political Science Association, Atlanta.

GBC (2006). Residents Show Satisfaction, About Guildford Newsletter, 01 March.

Gibson, R., Lusoli, W., \& Ward, S. (2002). UK Political Participation. The Public Response. A Survey of Citizens' Political Activity via the Internet. ESRC: Salford.

Gurstein, M. (2007). What is Community Informatics? (And Why Does It Matter). Milan: Polimetrica.

Heidegger, M. (2003) The Question Concerning Technology. Philosophy of Technology. In R. Scharff \& V. Dusek (Eds.), The Technological Condition (pp 252-264). Oxford: Blackwell Publishing.

Jensen, J. (2003). Public Spheres on the Internet: Anarchic or Government-Sponsored - A Comparison. Scandanvian Political Studies 26(4), 349-374.

Jensen, J., Clift, S., Erickson, T., \& Kranz, S. (2002). Minnesota E-Democracy Survey Report. Retrieved from http://www.edemocracy.org/research/edemsurvey2002-jakobjensen.pdf 
Kleiber, P., Holt, M., \& Swenson, J. (2007). The Electronic Forum Handbook - Study Circles in Cyberspace. Retrieved from http://www.cpn.org/tools/manuals/Networking/studycircles.html

Lengel, J. (2002). The Wed Wizard's Guide to Web Design. Boston: Addison Wesly.

Lowndes, V. \& Wilson, D. (2001). Social Capital and Local Governance: Exploring the Institutional Design Variable. Political Studies 49(4), 629-647.

Lowndes, V. Pratchett, L. \& Stoker, G. (2006 a). Locality Matters: Making Participation Count in Local Politics. London: IPPR.

Lowndes, V. Pratchett, L., \& Stoker, G. (2006 b). Local Political Participation: The Impact of Rules-in-Use. Public Administration 84(3), 539-62.

Lukensmeyer, C. \& Torres, L. (2006). Public Deliberation: A Manger's Guide to Citizen Engagement. Washington: IBM Center for the Business of Government.

Lynch, P. and Horton S. (2004). Yale Style Manual Graphic Design 100 - Web Style Guide. Retrieved from http://www.webstyleguide.com/about/copyright.html

Makrevski Z. (2004). Basic Web Design Principles. Retrieved from http://www.webpronews.com/webdevelopment/sitedesign/wpn-26-20041007BasicWebDesignPrinciples.html

McClurg-Genevese J D. (2005). The Principles of Design. Retrieved from http://www.digitalweb.com/articles/principles_of_design/

Mouffe, C. (2000). The Democratic Paradox. London: Verso.

Nielsen, J. (1999). Good Deeds in Web Design. Retrieved from http://www.useit.com/alertbox/991003.html

Nielsen, J. (2003). Usability 101: Introduction to Usability. Retrieved from http://www.useit.com/alertbox/20030825.html

Nielsen, J. (2004). Top Ten Mistakes in Web Design. Retrieved from http://www.useit.com/alertbox/9605.html

Noveck, B. (2004). Unchat: Democratic Solution for a Wired World. In P. Shane (Ed.), Democracy Online - The Prospects for Renewal Through the Internet (pp. 21-35). New York: Routledge.

OECD. (2003). Promise and Problems of E-Democracy: Challenges of Online Citizen Engagement. Paris: OECD.

Office of e-Government - Department of the Premier \& Cabinet. (2005). e-Engagement. Guidelines for Community Engagement. Using Information and Communication Technologies (ICT). Perth: Government of Western Australia.

Office of National Statistics. (2007). Internet 2007. Households and Individuals. London: Office of National Statistics.

Online Consultation Technologies - Centre of Expertise. (2004). Policy Development in the Network World: Online AgendaSetting and Decision Making. Retrieved from http://www.useit.com/alertbox/9605.html.

Onyx, J., \& Benton, P. (1995) Empowerment And Ageing: Toward Honoured Places for Crones and Sages. In G. Craig \& M. Mayo (Eds.), Community Empowerment. A Reader in Participation and Development. New Jersey: Zed books.

Pattie, C., Seyd, P. \& Whiteley, P. (2004). Citizenship in Britain. Values, Participation and Democracy. Cambridge: Cambridge University Press.

Pratchett, L. (2006). Making Local e-democracy Work?. In M. Virapatirin. \& T. Peixoto (Eds.), e-AGORA, Le Livre Blanc de la e-Démocratie Locale: Réflexions et Perspectives (pp. 319-331). Paris: Ville d'Issy-les-Moulineaux.

Pratchett, L., Wingfield, M., \& Karakaya-Polat, R. (2005) Barriers to e Democracy: Local Government Experiences and Responses. London: Local e Democracy National Project.

Preece, J. (2000). Online Communities - Designing Usability, Supporting Sociability. West Sussex: John Wiley \& Sons.

Preece, J. (2000). Online Communities: Designing Usability and Supporting Sociability. New York: John Wiley \& Sons.

Putnam, R. (1995). Bowling Alone: America's Declining Social Capital. Journal of Democracy 6, 65-78.

Trenel, M. (2004). Measuring the Deliberativeness of Online Discussions. Coding Scheme 2.4. Berlin: Social Science Research Centrex.

Trenel, M. (2005). Facilitating Deliberation Online: What Difference Does It Make. Paper presented at the $2^{\text {nd }}$ annual Conference on Online Deliberation, Stanford, California.

World Wide Web Consortium (W3C). (2004), Web Content Accessibility Guidelines 2.0 Draft. Retrieved from http://www.w3.org/TR/WCAG20/

Wright, S., \& Street, J. (2007). Democracy, Deliberation and Design: The Case of Online Discussion Forums. New Media and Society 9(5), 849-869.

UK Government (2011). The Localism Bill (2010 -2011). Retrieved from http://services.parliament.uk/bills/2010$11 /$ localism.html

\section{Appendices}

\section{Appendix A}

- This forum is for private citizens only. No national / local public representatives or representatives of business organizations may enter this forum. (This rule was deleted on the 03/11/05representatives were now allowed participate, but only by emailing me) All private citizens can post messages and deliberate within the GBC forum. However, to be eli- 
gible to vote within this forum participants must: be 18 years of age and over; live within the Guildford area; be a British, Commonwealth, or European citizen

- All posts must be signed by author's full name.

- Posts are not permitted to be emailed with attachments

- You cannot attack people verbally - You must be polite and civil to other participants. If content is illegal it will be forwarded to the appropriate legal authorities. Avoid false rumors, as you will be liable.

- Discussions within this forum are limited to the Guildford Borough Council issues highlighted for discussion and other related local issues. This forum is not a place for discussions of national or international issues.

- Finally, the forum moderator has the duty to clean and remove posts; and warn and remove participants who fail to comply with the online forum rules. If you transgress the rules, you will be given a first warning. If you receive a second warning you will be removed form the forum for two weeks. If you receive a third warning you will be removed from the forum indefinitely.

\section{About the Author}

Kerill Dunne received his Ph.D. from the University of Surrey, UK, in 2008. His primary areas of research are e-democracy and online forums. 